\title{
Cation-Exchange Equilibria in a Carboxylic Cation Exchanger and in Attapulgite Clay ${ }^{1}$
}

\author{
Gilberto García Monge ${ }^{2}$
}

\section{INTRODUCTION}

Base exchange, or in more modern terminology, cation exchange, has been the subject of much scientific investigation, most of which was carried out with clays. In 1845, the Englishman Thompson $(15)^{3}$ found by experiment that, when soil was mixed with ammonium salts and then leached with water, a great part of the ammonia remained in the soil. Thompson discussed his experiments with Thomas Way, who was then consulting chemist of the Royal Agricultural Society and who at once appreciated the significance of the results. Way investigated the base exchange so thoroughly that for a whole decade it was not followed by other comparable work. In his first paper, published in 1850, Way reported a large number of experiments. He formulated eight laws of base exchange. He showed that the total absorption and base exchange are caused by the compounds of silicic acid with aluminum. At this time nothing was known of the law of mass action, which was discovered later by Guldberg and Waage (15).

The first practical application of ion exchange for analytical purposes was achieved by Folin and Bell $(10)$ in the determination of ammonia in urine. It was found that ammonia was absorbed when the solution was shaken with a synthetic zeolite, whereas the interfering substances remained in solution. The principle of column operation was introduced into analytical chemistry by Whitehorn (14), who used a synthetic zeolite as a reagent for amines.

A comprehensive knowledge of the laws governing the distribution of ions between the solution and the ion exchanger would facilitate considerably the selection of the most suitable conditions in which to employ different exchangers for various analytical and technical purposes. Among the most important of these properties are the relative affinity coefficients, or selectivity coefficients, which also have been called "concentration equilibrium quotients" and "apparent equilibrium constants." With two ex-

${ }^{1}$ Abstract of a thesis submitted to the faculty of the Graduate School of the University of Missouri, Columbia, Mo., in partal fulfillment of the requirements for the degree of Master of Science.

2 Research Assistant in Chemistry, Agricultural Experiment Station, University of Puerto Rico, Río Piedras, P. R. The author wishes to express his sincere appreciation to Dr. C. E. Marshall for the kind advice given during this investigation.

${ }^{3}$ Italic numbers in parentheses refer to Literature Cited, pp. 234-5. 
changeable ions, the difference in affinity is manifested by a difference between the ratio of the amounts of the two ions on the exchanger and in the solution in equilibrium. The ease and efficiency of separations by ion-exchange chromatography is determined by the relative affinities of the ions concerned. Thus a knowledge of the relative affinities of different ions for various resins should be of immediate practical value, while at the same time providing a better insight into the nature of the ion-exchange process and the structure of the resin.

Aside from ionic-exchange chromatography, selectivity coefficients may have importance in soil studies and in some industrial problems. The fixation of fertilizers added to the soil is a classical problem of applied ionic exchange.

In these studies the term "selectivity number" will be used instead of selectivity coefficient or relative affinity coefficient.

The present study was undertaken with the purposes of:

1. Determining the selectivity number for a series of monovalent cations in both a resinous cation exchanger and a clay mineral.

2. Determining the selectivity number for a series of divalent cations in a resinous cation exchanger and a clay mineral.

\section{REVIEW OF LITERATURE}

Wiegner $(15,16)$, in 1931, investigated cation exchange from the standpoint of colloid chemistry. According to Wiegner, cation exchange is an adsorption reaction and not an ordinary chemical reaction.

Lowen, et al. (6), in 1952, investigated exchange systems on Dowex 50, involving the ions $\mathrm{Na}^{+}, \mathrm{H}^{+}, \mathrm{NH}_{4}+, \mathrm{Tl}^{+++}, \mathrm{Ni}^{++}$, and $\mathrm{Ca}^{++}$in solutions of total ionic strength of approximately unity. The effect of the nature of the anion in solution on the exchange equilibria was found to be negligible. In every exchange system studied, the apparent equilibrium constant was found to vary regularly with the equilibrium resin composition.

Spinner, et al. (11), in 1954, said that the observed variation in the relative affinity or equilibrium quotient of ion-exchange resins prepared by the sulphonation of polystyrene have been considered on the implicit assumption that all the sulfonic groups are identical. In order to test the hypothesis of the significant departure of equilibrium quotients due to nonidentity of sulphonic groups, they prepared monomers with different reactivity ratios from styrene-divinylbenzene. They concluded that cross-linking and capacity were insufficient to characterize a resin of the polystyrenesulfonic type. Variation in the detailed structure was suggested as a possible explanation for the variation of the equilibrium quotients.

Wiklander (16), in 1946, using the Donnan equation and assuming that the volume of the micellar solution remains constant, computed the ex- 
change constant for Wofatit $K$. The $k$ values for the $\mathrm{K}^{+}-\mathrm{NH}_{4}{ }^{+}, \mathrm{Na}^{+}-\mathrm{NH}_{4}{ }^{+}$, $\mathrm{Li}^{+}-\mathrm{NH}_{4}+$ changed but slightly, despite the fact that the concentration ratio used varied between 9:1 and 1:9. The slight differences in $k$ values were attributed to differences in activity coefficients.

Bauman and Eichhorn (1), in 1947, arrived at the same equation and same conclusion as derived from the mass action law by treating exchange equilibria as a Donnan distribution of two salts between an aqueous phase and the resin phase. They were the first to propose that the resinate should be regarded as a concentrated electrolyte solution having an activity coefficient similar to that in ordinary solutions.

\section{DONNAN THEORY AND EXCHANGE REACTIONS}

These studies involve the measure of the selectivity number based on the Donnan Theory $(2,12)$. W. Ostwald appears to have been the first to direct attention to the interesting electrical and other effects which must arise in a system consisting of two solutions of electrolytes separated by a membrane which is permeable to most of the species of ions present, but is impermeable to at least one species. Some years later, Donnan, realizing the importance of the phenomenon, proceeded to develop a simple thermodynamic theory for this unequal distribution of ions which he called Donnan Equilibrium. After the appearance of the first work on the Donnan Equilibrium other works appeared that demonstrated the existence of the equilibrium.

On extending the Donnan theory $(5,10)$ to the phenomenon of ion exchange, the assumption is made that the colloidal micelle to which is attached the exchangeable ion is the nondiffusible ion. Although no membrane is encountered in ion-exchange equilibria, the interface between the solid and liquid phases may be considered as a membrane. Consider the reaction taking place between a carboxylic resin in the $\mathrm{Na}$ form and two neutral salts, e.g., $\mathrm{NaCl}, \mathrm{KCl}$. According to the Donnan theory the following two conditions must be obeyed:

$$
\begin{aligned}
{\left[\mathrm{Na}^{+}\right]_{1}\left[\mathrm{Cl}^{-}\right]_{1} } & =\left[\mathrm{Na}^{+}\right]_{2}[\mathrm{Cl}]^{-} \\
{\left[\mathrm{K}^{+}\right]_{1}\left[\mathrm{Cl}^{-}\right]_{1} } & =\left[\mathrm{K}^{+}\right]_{2}\left[\mathrm{Cl}^{-}\right]_{2}
\end{aligned}
$$

Dividing the two equations we obtain:

$$
\frac{\left[\mathrm{Na}^{+}\right]_{1}}{\left[\mathrm{~K}^{+}\right]_{1}}=\frac{\left[\mathrm{Na}^{+}\right]_{2}}{\left[\mathrm{~K}^{+}\right]_{2}} \quad \begin{aligned}
& 1, \text { side of the nondiffusible ion } \\
& \text { 2, outer solution }
\end{aligned}
$$

For real solutions, activities should be substituted for concentrations, Then the above expression may be rewritten:

$$
\frac{\left[\mathrm{Na}^{+}\right]_{1} f_{\mathrm{Na}_{1}}}{\left[\mathrm{~K}^{+}\right]_{1} f_{\mathrm{K}_{1}}}=\frac{\left[\mathrm{Na}^{+}\right]_{2} f_{\mathrm{Na}_{2}}}{\left[\mathrm{~K}^{+}\right]_{2} f_{\mathrm{K}_{2}}}
$$


When the law of mass action is applied the following formula results:

$$
{ }_{\mathbf{K}}^{\mathrm{Na}} K_{s}=\frac{\left[\mathrm{Na}^{+}\right]_{2}}{\left[\mathrm{~K}^{+}\right]_{2}} \cdot \frac{\left[\mathrm{K}^{+}\right]_{1}}{\left[\mathrm{Na}^{+}\right]_{1}}
$$

In the derivation of equation 1 the assumption is made that at high dilutions the mean activity coefficient ratio of two electrolytes of the same valence type is unity. The value of ${ }_{R}^{N_{R}} K_{s}$ has been given different names, but in these studies the term selectivity number will be employed.

\section{MATERIALS AND METHODS}

To the knowledge of the author no work has been done on selectivity numbers which fulfills the following conditions:

1. Sodium as standard for the comparison with other members of the alkali family $\left(\mathrm{K}^{+}, \mathrm{Rb}^{+}, \mathrm{Cs}^{+}\right)$.

2. Magnesium as a standard for the comparison with other members of the alkaline earths $\left(\mathrm{Ca}^{++}, \mathrm{Sr}^{++}\right.$, and $\left.\mathrm{Ba}^{++}\right)$.

3. IRC-50 as a carboxylic type of exchanger of the resinous type and attapulgite clay mineral as a natural type of exchanger.

4. Dilute solutions in the range of $10^{-2} \mathrm{~N}$ to $10^{-3} \mathrm{~N}$.

5. Experimental determination of the selectivity number for different proportions of each pair of cations in solution.

6. The technique used for these studies limits the systems to the two types of cations under investigation. The method is developed in such a way as to exclude the $\mathrm{H}^{+}$from the system.

\section{EXCHANGE RESIN-DESCRIPTION AND PROCEDURE}

Cation-exchange resins are high polymeric cross-linked structures containing polar anionic groups whose charges are balanced by cations. The essential characteristic distinguishing the ion-exchange resin is its insolubility. The extent of swelling in water depends on the concentration of active groups as well as upon the extent of the cross-linking. All ion-active groups tend to solubilize the structure, while the cross-links prevent dissolution. The result of these opposing forces is a limited swelling in water.

The resin used in these studies was Amberlite IRC-50. Its exchange capacity is derived from carboxylic groups. Supplied in hydrogen form, Amberlite IRC-50 can be converted into the sodium salt by reacting with $\mathrm{NaOH}$. In the sodium form the resin undergoes reactions typical of the salt of a weak acid and strong base.

In the $\mathrm{Na}^{+}-\mathrm{K}^{+}$system the equilibria were defined in the following way: One gram of resin was weighed into each of 12 calibrated plastic tubes. A total of 100 m.e. of chlorides of $\mathrm{Na}^{+}$and $\mathrm{K}^{+}$was added in different proportions to give 0 to 100 percent of $\mathrm{Na}^{+}$in the system. The resin samples were 
mixed thoroughly and allowed to come to equilibrium. After decantation, the outer solutions were analyzed for $\mathrm{Na}^{+}$and $\mathrm{K}^{+}$, using a Perking Elmer Model No. 52A Flame Photometer. A mixture containing known concentrations of $\mathrm{Na}^{+}$and $\mathrm{K}^{+}$was analyzed for $\mathrm{Na}^{+}$and $\mathrm{K}^{+}$and no interference of $\mathrm{K}^{+}$on sodium or sodium in $\mathrm{K}^{+}$was found on the mixture.

After separation of the outer solution the resins were leached with $1 \mathrm{~N}$ $\mathrm{NH}_{4} \mathrm{NO}_{3}$ and the filtrate collected into a $100-\mathrm{ml}$. volumetric flask. The leachates were analyzed in the way described above regarding $\mathrm{Na}^{+}$and $\mathrm{K}^{+}$. The chloride concentration was determined on each sample by the Mercuric Nitrate titration as outlined by Metson (8). The chloride concentration was in the vicinity of $10^{-5} \mathrm{~N}$. This is in agreement with the Domnan theory, since the chloride is negatively adsorbed by the resin.

For the $\mathrm{Na}^{+}-\mathrm{Cs}^{+}$and $\mathrm{Na}^{+}-\mathrm{Rb}^{+}$systems the technique used was the same as described for $\mathrm{Na}^{+}-\mathrm{K}^{+}$system. Mixtures of known concentrations of $\mathrm{Na}^{+}-\mathrm{Rb}^{+}$and $\mathrm{Na}^{+}-\mathrm{Cs}^{+}$were tested for interference at their respective emission lines. No interference was observed.

For the $\mathrm{Mg}^{++}-\mathrm{Ca}^{++}$system $0.5000 \mathrm{gm}$. of resin was weighed into each of 12 calibrated plastic tubes. A total of 25 m.e. of $\mathrm{Mg}^{++}$and $\mathrm{Ca}^{++}$was added to provide from 0 to 100 percent of $\mathrm{Mg}^{++}$in the system. The resins with the different percentages of $\mathrm{Mg}^{++}$and $\mathrm{Ca}^{++}$were mixed thoroughly and allowed to come to equilibrium.

Calcium plus magnesium was determined by the Versenate titration as outlined by Metson (8). Calcium was determined using the Perkin Elmer Flame Photometer. A mixture containing known concentrations of $\mathrm{Mg}^{++}$ and $\mathrm{Ca}^{++}$was analyzed for $\mathrm{Ca}^{++}$on the flame photometer. No interference was observed since the emission line of $\mathrm{Mg}^{++}$could not be detected with the instrument.

After separation of the outer solution the resins were leached with $1 \mathrm{~N}$ $\mathrm{NH}_{4} \mathrm{NO}_{3}$ in the same way as described for $\mathrm{Na}^{+}-\mathrm{K}^{+}$system. The leachates were analyzed as described above for the outer solution.

For the $\mathrm{Mg}^{++}-\mathrm{Sr}^{++}$and $\mathrm{Mg}^{++}-\mathrm{Ba}^{++}$systems the technique used was the same as described for the $\mathrm{Mg}^{++}-\mathrm{Ca}^{++}$system. The total concentration of $\mathrm{Mg}^{++}$plus $\mathrm{Sr}^{++}$was determined by the Versenate titration as described by Martell and Calvin (7). Strontium was determined using the flame photometer.

In the determination of $\mathrm{Mg}+\mathrm{Ba}$, using the Versenate titration, the end-point was not sharp. A modification similar to the one used by Crook and Yardley (13) was used for these titrations. Analytical difficulties were encountered at high concentrations of $\mathrm{Ba}^{++}$on the flame photometer, probably due to instability of the barium band.

Under the experimental conditions adopted in these systems the measured concentrations on the flame photometer are believed reliable in 1 p.p.m. 


\section{ATTAPULGITE CLAY-DESCRIPTION AND PROCEDURE}

The attapulgite clay mineral was used as supplied by Wards Natural Science Establishment. It is a hydrous aluminum magnesium silicate of the polygorskite group. Its structure as worked out by Bradley is as follows: The silica sheets are in a sense continuous, but the silicon atoms occur in strips arranged alternately on either side of the oxygen. The fourth valency of the silicon links the sheets with the alumina-Mg sheets which are in strips to correspond. The "a" axis of attapulgite corresponds to the "c" axis of micas. In attapulgite the main substitution is three magnesium for two aluminum atoms in the octahedral coordination. The adsorbed water lies in fixed channels running parallel to the amphibole chains and the exchangeable cations likewise lie in these openings. The chemical analysis shows that the principal exchangeable ion is calcium, but $\mathrm{Mg}, \mathrm{K}$, and $\mathrm{Na}$ may be found in small amounts.

One gram of the 40-mesh air-dry clay was weighed into each of 12 calibrated plastic tubes. A total of $25 \mathrm{~m}$.e. of $\mathrm{Na}^{+}$and $\mathrm{K}^{+}$as chlorides was added to provide from 0 to 100 percent $\mathrm{Na}^{+}$. The clay samples with the different percentages of $\mathrm{Na}^{+}$and $\mathrm{K}^{+}$were mixed thoroughly and allowed to come to equilibrium.

After centrifugation, the outer solutions were analyzed for $\mathrm{Na}^{+}, \mathrm{K}^{+}$, and $\mathrm{Cl}^{-}$using the method described above for the resin.

The clay phase was leached with $1 \mathrm{~N} \mathrm{NH}_{4} \mathrm{NO}_{3}$, using the leaching technique used for $\mathrm{Na}^{+}-\mathrm{K}^{+}$system on the resin. The leachates were analyzed for $\mathrm{Na}^{+}, \mathrm{K}^{+}$, and $\mathrm{Cl}^{-}$by the method described above for the resin.

The technique used for the $\mathrm{Na}^{+}-\mathrm{Rb}^{+}$and $\mathrm{Na}^{+}-\mathrm{Cs}^{+}$systems was that described above for the $\mathrm{Na}^{+}-\mathrm{K}^{+}$system. The chemical analysis for $\mathrm{Na}^{+}$, $\mathrm{Rb}^{+}, \mathrm{Cs}^{+}$, and $\mathrm{Cl}^{-}$on the outer solution and leachates were also made as described for the resin.

In the preparation of the $\mathrm{Mg}^{++}-\mathrm{Ca}^{++}, \mathrm{Mg}^{++} \mathrm{Sr}^{++}$, and $\mathrm{Mg}^{++}-\mathrm{Ba}^{++}$systems the technique followed was the same as for the $\mathrm{Na}^{+}-\mathrm{K}^{+}$system. The chemical analysis for $\mathrm{Mg}^{++}, \mathrm{Ca}^{++}, \mathrm{Sr}^{++}, \mathrm{Ba}^{++}$, and $\mathrm{Cl}^{-}$in the outer solution and leachates were also made as for the resin systems.

\section{RESULTS AND DISCUSSION}

\section{RESIN DATA}

The results of these studies, using IRC-50 with the alkali metals $\mathrm{Na}^{+}$, $\mathrm{K}^{+}, \mathrm{Rb}^{+}$and $\mathrm{Cs}^{+}$, showed no marked selectivity. The total cation concentration in the resin phase was in the vicinity of $1.7 \mathrm{~m} . \mathrm{e} . / \mathrm{gm}$. of resin. The resin phase may be considered to be a concentrated salt solution, whereas the outer solution is a dilute solution $\left(10^{-8} \mathrm{~N}\right)$. Hence the differences in the selectivity number $\left(K_{s}\right)$ may be attributed to the differences in the activity coefficients in the concentrated resin phase solution. 
The results for the selectivity numbers of the $\mathrm{Na}^{+}-\mathrm{K}^{+}, \mathrm{Na}^{+}-\mathrm{Rb}^{+}$, and $\mathrm{Na}^{+}-\mathrm{Ca}^{+}$systems are shown in figure 1.

These results suggest the following conclusions:

In the region from 45 to 85 percent of $\mathrm{Na}^{\circ}$ in the resin, the selectivity numbers $\left(K_{s}\right)$ are in the order ${ }_{R}^{\mathrm{Na}} K_{s}={ }_{\mathrm{Rb}}^{\mathrm{Na}} K_{s}<{ }_{\mathrm{C}_{\mathrm{g}}}^{\mathrm{Na}_{s}} K_{s}$. This may be related to the activity coefficients for $\mathrm{Na}, \mathrm{K}, \mathrm{Rb}$, and $\mathrm{Cs}$ in the resin phase. The percentages of $\mathrm{Na}$ in the resin are less than the percentages of sodium in

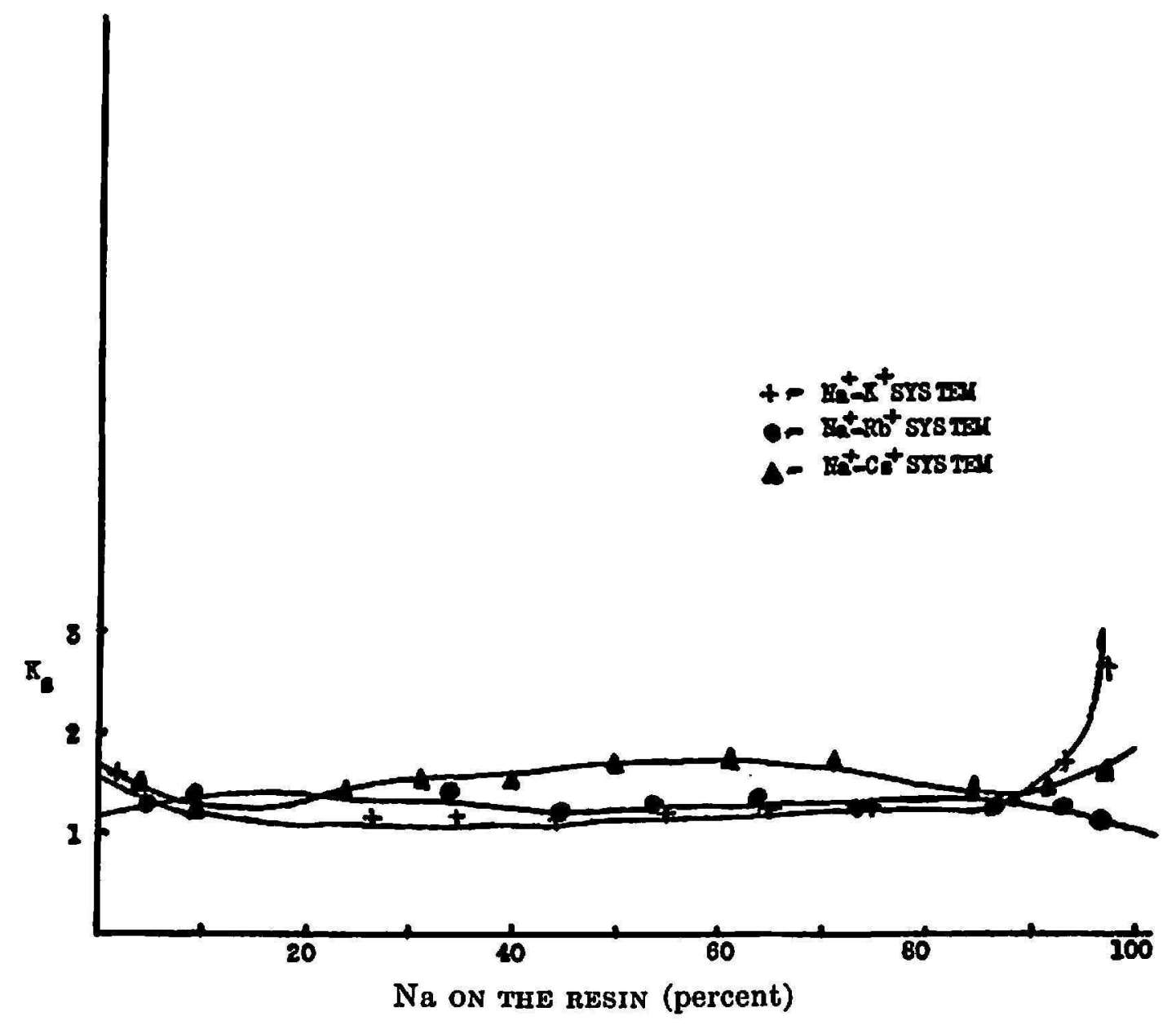

Fig. 1.-Influence of resinate composition (percentage of $\mathrm{Na}$ ) on the selectivity number $\left(K_{s}\right)$ of IRC-50 for $\mathrm{Na}^{+}-\mathrm{K}^{+}, \mathrm{Na}^{+}-\mathrm{Rb}^{+}$, and $\mathrm{Na}^{+}-\mathrm{Cs}^{+}$systems.

the whole system. The percentages of sodium in the resin for the systems are in the order $\mathrm{Na}^{+}-\mathrm{K}^{+}=\mathrm{Na}^{+}-\mathrm{Rb}^{+}$system $<\mathrm{Na}^{+}-\mathrm{Cs}^{+}$system.

If the ionic equilibrium in an exchanger is expressed by the law of mass action as well as by the Donnan equilibrium, it should be possible to pass from the former into the latter. By deriving the law of mass action kinetically it is possible to show that the equilibrium constant must have a value of 1 . Boyd, et al., (3), in 1947, found the same order of affinity for $\mathrm{Na}, \mathrm{Rb}$, and Cs, using the mass-action relationship. They also made a correlation between the selectivity number values and the parameter $a^{\circ}$ in the Debyl Huckel approximation for the activity coefficient. 
The small differences in selectivity of this resin between the members of the alkali metal series were correlated with the fact that there also exist small differences in activity coefficient between the $\mathrm{Na}^{+}, \mathrm{K}^{+}, \mathrm{Rb}^{+}$, and $\mathrm{Cs}^{+}$ acetates in $1 \mathrm{~N}$ solutions. These values of activity coefficients range from $0.76-0.80$ for the $1 \mathrm{~N}$ solutions of the acetates.

In the alkaline-earth series $\left(\mathrm{Mg}^{++}, \mathrm{Ca}^{++}, \mathrm{Sr}^{++}\right.$, and $\left.\mathrm{Ba}^{++}\right)$the resin

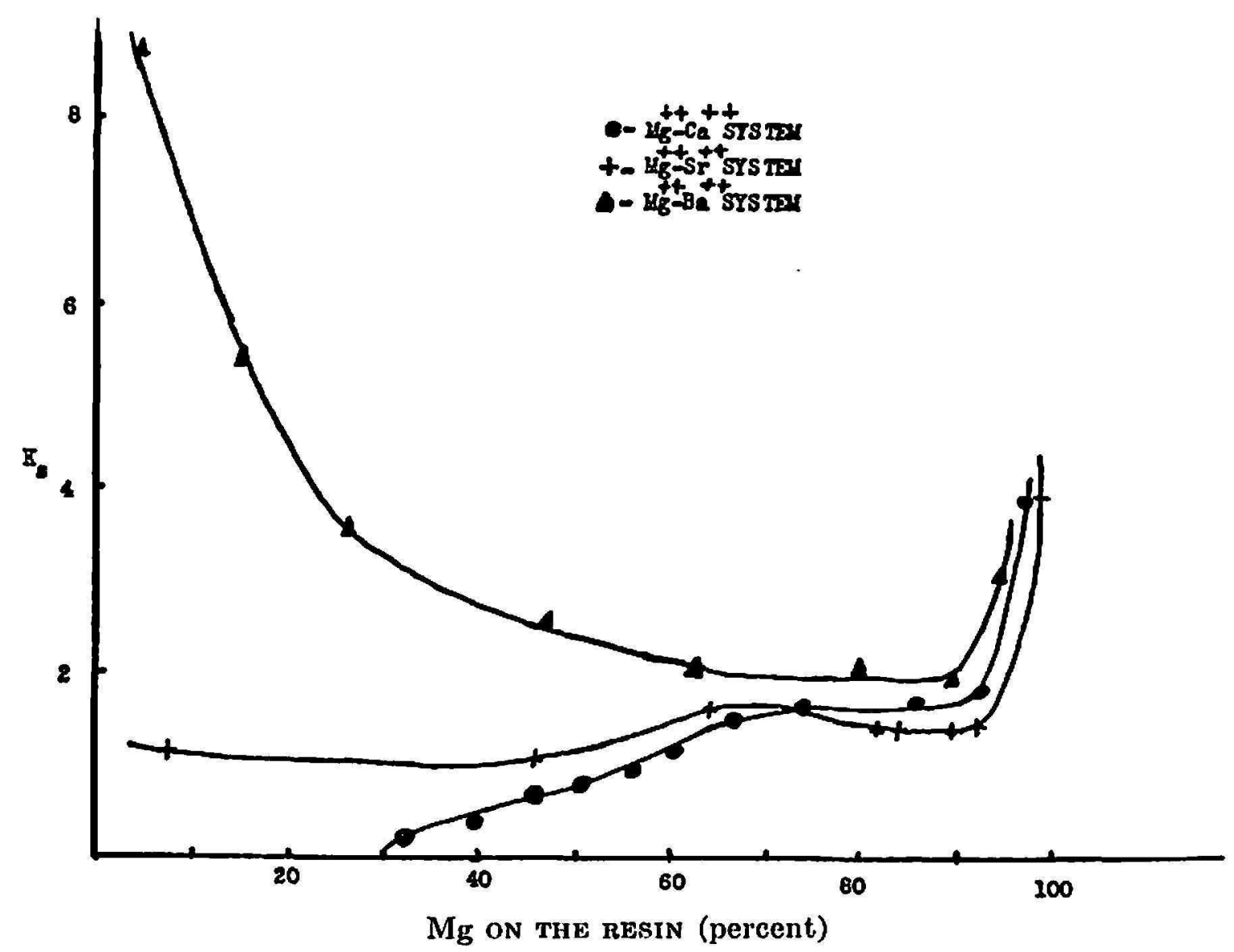

FIG. 2.-Influence of resinate composition (percentage of $\mathrm{Mg}^{++}$) on the selectivity number $\left(K_{s}\right)$ of IRC-50 for $\mathrm{Mg}^{++}-\mathrm{Ca}^{++}, \mathrm{Mg}^{++}-\mathrm{Sr}^{++}$, and $\mathrm{Mg}^{++}-\mathrm{Ba}^{++}$systems.

showed more selectivity between its members than between the members of the alkali series.

The resin phase may be regarded as an jonic solution similar to the previous straight-chain organic acids used to build up the resin structure by the process of polymerization. Methacrylic acid was used to build up the resin network in IRC-50. It has been suggested that the alkaline-earth cations may form slightly dissociated complexes with the carboxylic group. The properties of IRC-50 have been related to the polybasic carboxylic acids that exhibit sequestering ability for the alkaline-earth cations.

The results for the selectivity numbers of the $\mathrm{Mg}^{++}-\mathrm{Ca}^{++}, \mathrm{Mg}^{++}-\mathrm{Sr}^{++}$, and $\mathrm{Mg}^{++}-\mathrm{Ba}^{++}$systems are shown in figure 2 .

These results suggest the following: 
1. The selectivity numbers for the $\mathrm{Mg}^{++} \mathrm{Ca}^{++}, \mathrm{Mg}^{++} \mathrm{Sr}^{++}$, and $\mathrm{Mg}^{++}$ $\mathrm{Ba}^{++}$systems are functions of the percentage of magnesium in the resin.

2. In figure 2, the selectivity numbers increase in the order ${ }_{\mathrm{gr}}^{\mathrm{Mg}} K_{s}<$ ${ }_{\mathrm{Ca}}^{\mathrm{Mg}} K_{\mathrm{s}}<{ }_{\mathrm{Ba}}^{\mathrm{Mg}_{\mathrm{g}}} K_{\mathrm{s}}$ in the region between 70 and 99 percent of $\mathrm{Mg}$ in the resin. The order is reversed with respect $\mathrm{Mg}^{++}-\mathrm{Ca}^{++}$, and $\mathrm{Mg}^{++} \mathrm{Sr}^{++}$systems in the region from 5 to 69 percent of magnesium. The resin shows a marked selectivity for barium at low percentages of $\mathrm{Mg}$ on the resin.

3 . In the $\mathrm{Mg}^{++}-\mathrm{Ca}^{++}$system, magnesium appears more strongly held than calcium in the region between 30 and 56 percent of magnesium in the resin. In this region magnesium appears to form a stronger complex than calcium.

These selectivity numbers may be understood by assuming the formation of slightly dissociated complexes with the carboxylic groups. At low percentages of $\mathrm{Ca}, \mathrm{Sr}$, and $\mathrm{Ba}$ in the resin, the tendency to form complexes increases in the order $\mathrm{Sr}<\mathrm{Ca}<\mathrm{Ba}$. At higher percentages the order is $\mathrm{Ca}<\mathrm{Sr}<\mathrm{Ba}$.

\section{ATTAPULGITE CLAY MINERAL}

The selective-number curves for the alkali metals ( $\mathrm{Na}, \mathrm{K}, \mathrm{Rb}$, and $\mathrm{Cs}$ ) in the clay mineral resemble those of a bifunctional cation exchanger. Cornay and Deul, (4), in 1956, studied the relative affinity coefficient in a mixture of Dowex 50 (sulfonate resin) with Amberlite IRC-50 (carboxylic resin) and, in Lewatit $\mathrm{H}-236$, which contains carboxylic and sulfonic groups in the same structure. They obtained S-shaped ion-exchange curves. This was interpreted as being due to opposite selectivity for the two ions by the two acid groups. The curves had a pronounced flat part only for the mixture of exchangers. Lewatit $\mathrm{H}-236$ did not show pronounced flattening of the curve. This was interpreted as being due to interaction of the acid groups of Lewatit H-236.

It is known that, in the formation of the more important cation-exchange clays, the arrangement of the electronegative $\mathrm{O}^{-}$and $\mathrm{OH}^{-}$ion and the electropositive $\mathrm{Si}^{++++}, \mathrm{Al}^{+++}, \mathrm{Fe}^{++}$, and $\mathrm{Mg}^{++}$is such as to necessitate the absorption of cations from the medium, in addition to those in the structural framework of the crystal lattice. By analogy with the work of Cornay and Deul one might regard the clay as being bifunctional in character. The functional groups can be the balancing cations and $\mathrm{OH}^{-}$located in the fixed channels of the crystal.

The results for the selectivity number of the $\mathrm{Na}^{+}-\mathrm{K}^{+}, \mathrm{Na}^{+}-\mathrm{Rb}^{+}$, and $\mathrm{Na}^{+}-\mathrm{Cs}^{+}$systems are shown in figure 3 .

These results suggest the following:

1. The selectivity numbers for the $\mathrm{Na}^{+}-\mathrm{K}^{+}, \mathrm{Na}^{+}-\mathrm{Rb}^{+}$, and $\mathrm{Na}^{+}-\mathrm{Cs}^{+}$systems are functions of the percentage of $\mathrm{Na}$ in the clay.

2. The differences in selectivity are greater in the $\mathrm{Na}^{+}-\mathrm{Cs}^{+}$system than 
in the $\mathrm{Na}^{+}-\mathrm{Rb}^{+}$system and, in the $\mathrm{Na}^{+}-\mathrm{Rb}^{+}$system, are greater than in the $\mathrm{Na}^{+}-\mathrm{K}^{+}$system. A pronounced flat portion is not observed in the $\mathrm{Na}^{+}-\mathrm{C}_{s}{ }^{+}$and $\mathrm{Na}^{+}-\mathrm{Rb}^{+}$systems, probably due to interaction between the exchange functional groups.

3. The selectivity numbers follow the normal hydration series since they increase in the order ${ }_{\mathrm{K}}^{\mathrm{Na}} K_{s}<{ }_{\mathrm{nb}}^{\mathrm{Na}} K_{s}<{ }_{\mathrm{Cs}}^{\mathrm{Na}} K_{s}$.

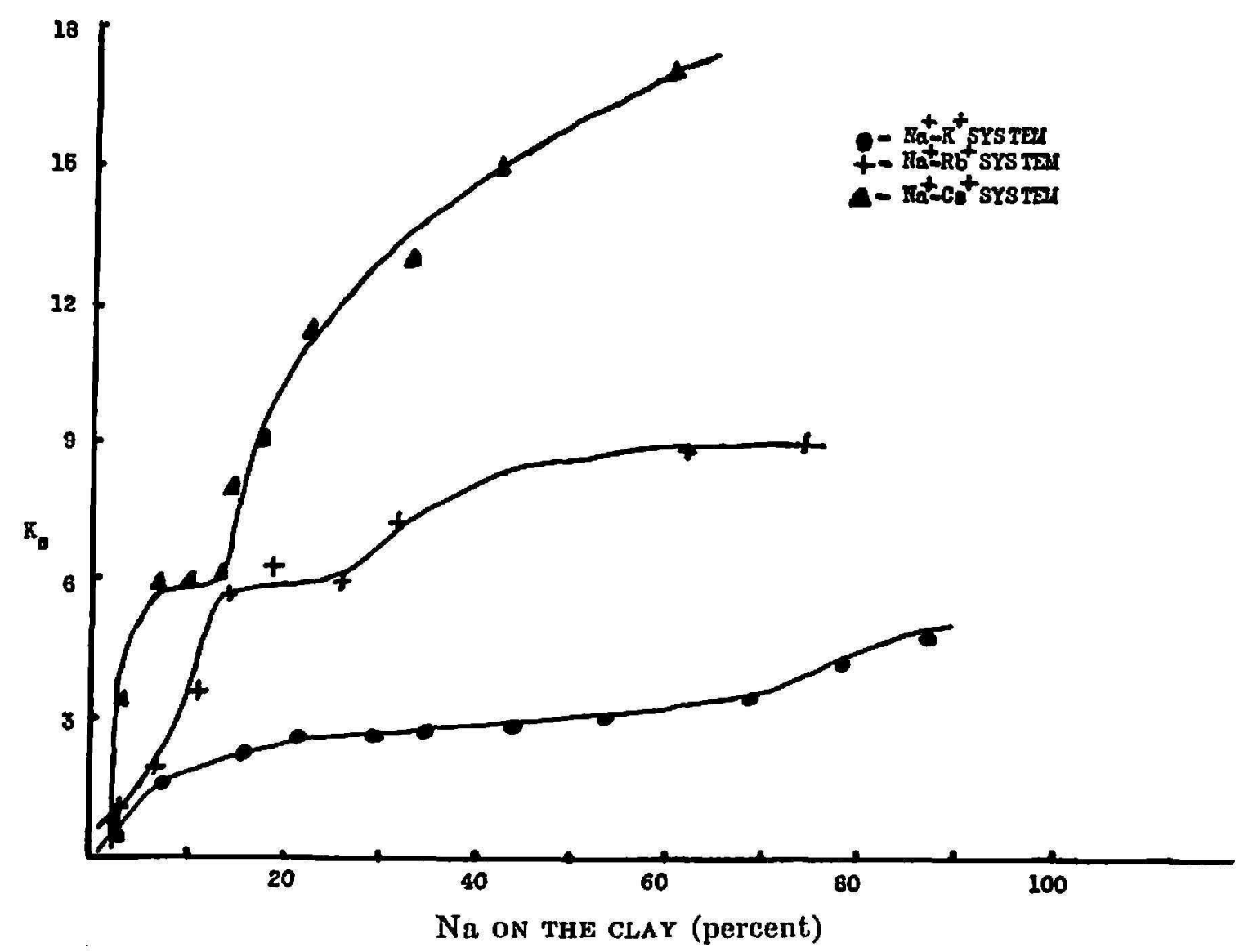

Fra. 3.- Influence of clay composition (percentuge of $\mathrm{Na}$ ) on the selectivity number $\left(K_{\bullet}\right)$ of attapulgite for $\mathrm{Na}^{+}-\mathrm{K}^{+}, \mathrm{Na}^{+}-\mathrm{Rb}^{+}$, and $\mathrm{Na}^{+}-\mathrm{Cs}^{+}$systems.

Reichenbert, et al. (9), in 1951, determined the relative affinity coefficients $K_{H}^{\mathrm{Na}}$ of $\mathrm{Na}^{+}$and $\mathrm{H}^{+}$for a polystyrene sulfonate resin of a high cross-linkage. They found that $K_{H}^{\mathrm{Na}}$ decreased sharply with increasing $X_{\mathrm{RNa}}$, becoming less than unity at high values of $X_{\mathrm{RNa}} . K_{H}^{\mathrm{Na}}$ was approximately unity for resins of low cross-linking, and was independent of mole fraction of $\mathrm{Na}$ in resin $\left(X_{\mathrm{RNa}}\right)$ when it varied from 0.3 to 0.8 . These results may be broadly understood in relation to swelling. In a high cross-linking resin the swelling is much less than in a low cross-linking one. If an exchanger is so swollen that cations can be just as hydrated within its pore as in the bulk of the solution it will not distinguish between different cations. Attapulgite is a rigid structure and may be compared to a high cross-linkage resin. Ions are 
closer together in high cross-linkage, resembling a concentrated solution. In concentrated solutions there is more interaction between ions and individual ion differences become more apparent.

The differences in selectivity number are small for the alkaline-earth metals $(\mathrm{Mg}, \mathrm{Ca}, \mathrm{Sr}, \mathrm{Ba})$ as compared with those of the alkali metals. These differences may be explained on the basis of hydration, since the pores of

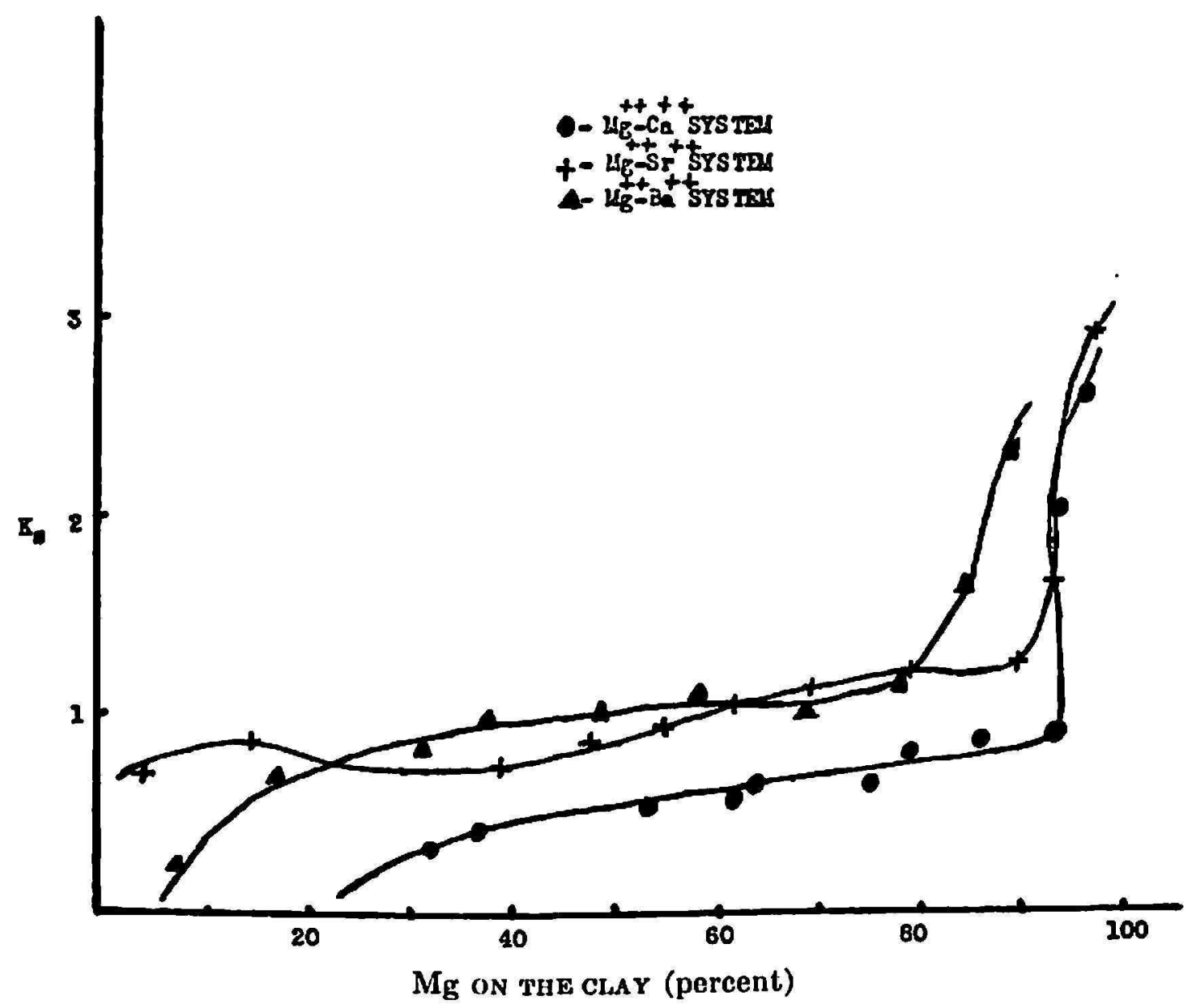

FIa. 4.-Influence of clay composition (percentage of $\mathrm{Mg}^{++}$) on the selectivity number $\left(K_{\mathfrak{s}}\right)$ of attapulgite for $\mathrm{Mg}^{++}-\mathrm{Ca}^{++}, \mathrm{Mg}^{++}-\mathrm{Sr}^{++}$, and $\mathrm{Mg}^{++}-\mathrm{Ba}^{++}$systems.

attapulgite are in a fixed size. The alkali metals being monovalent will be more abundant in the pore than the divalent alkaline-earth metals. The vacancy left by the monovalent cations is occupied by $\mathrm{H}_{2} \mathrm{O}$ when the divalent cations are in the pores. If the water content increases in the clay phase, possibly the hydration of cations also increases. The exchanger will not distinguish between cations that are just as hydrated within the pore as in the bulk of the solution.

The results for the selectivity numbers of the $\mathrm{Mg}^{++} \mathrm{Ca}^{++}, \mathrm{Mg}^{++} \mathrm{Sr}^{++}$, and $\mathrm{Mg}^{++}-\mathrm{Ba}^{++}$systems are shown in figure 4.

These results suggest the following: 
1. At a high percentage of $\mathrm{Mg}$ in the clay (80 to 97 percent) the selectivity numbers $\left(K_{s}\right)$ increase in the order ${ }_{\mathrm{Ca}}^{\mathrm{Mg}} K_{s}<{ }_{\mathrm{Br}}^{\mathrm{Mg}_{8}} K_{s}<{ }_{\mathrm{Ba}}^{\mathrm{Mg}_{\mathrm{g}}} K_{\mathrm{s}}$. The activity coefficients for $\mathrm{Mg}^{++}, \mathrm{Ca}^{++}, \mathrm{Sr}^{++}$, and $\mathrm{Ba}^{++}$increase in the order $\mathrm{Ba}^{++}<$ $\mathrm{Sr}^{++}<\mathrm{Ca}^{++}<\mathrm{Mg}^{++}$.

2. At lower percentages of $\mathrm{Mg}$ ( 5 to 60 percent) the order is reversed with respect to $\mathrm{Mg}$. The values of the selectivity numbers fall below unity, meaning that $\mathrm{Mg}$ appears more strongly held than $\mathrm{Ca}, \mathrm{Sr}$, and $\mathrm{Ba}$. This suggests that there are other effects beside hydration which affect the entry of ions into the exchanger. It has been suggested by Wiegner (15), in 1931, that these effects are related to the solubility of the magnesium hydroxide. It has been established by infrared analysis of attapulgite that it contains $\mathrm{OH}^{-}$ in the lattice. Since magnesium hydroxide is less soluble than strontium hydroxide and barium hydroxide, the exchange by displacement will be more difficult the less soluble is the hydroxide.

3. The $S$ shape of these curves may be related to the polyfunctional nature of the clay. At low percentages of $\mathrm{Ca}^{++}, \mathrm{Sr}^{++}$, and $\mathrm{Ba}^{++}$in the clay the balancing cations dominate the affinity of the clay. At higher percentages of $\mathrm{Ca}^{++}, \mathrm{Sr}^{++}$, and $\mathrm{Ba}^{++}$, the $\mathrm{OH}^{-}$dominates the affinity of the clay. The results suggest less interaction between $\mathrm{OH}^{-}$and balancing cation groups.

\section{SUMMARY}

Selectivity numbers for a synthetic cation exchanger of the carboxylic type (IRC-50) and the natural cation exchanger, attapulgite clay mineral, were determined for different pairs of cations.

The results in IRC-50 for $\mathrm{Na}^{+}-\mathrm{K}^{+}, \mathrm{Na}^{+}-\mathrm{Rb}^{+}$, and $\mathrm{Na}^{+}-\mathrm{Cs}^{+}$systems showed no marked selectivity. The resin phase was considered to act as a concentrated salt solution. Hence, differences in the selectivity numbers $\left(K_{s}\right)$ were attributed to the differences in the activity coefficients in the concentrated resin-phase solution.

In the alkaline-earth systems $\left(\mathrm{Mg}^{++}-\mathrm{Ca}^{++}, \mathrm{Mg}^{++} \mathrm{Sr}^{++}\right.$, and $\left.\mathrm{Mg}^{++}-\mathrm{Ba}^{++}\right)$ the resin showed more selectivity between its members than between those of the alkali series. The selectivity numbers were functions of the percentage of $\mathrm{Mg}$ in the resin. In the $\mathrm{Mg}^{++} \mathrm{Ca}^{++}$system, $\mathrm{Mg}^{++}$appeared more strongly held at low percentages of $\mathrm{Mg}$, whereas in the $\mathrm{Mg}^{++}-\mathrm{Ba}^{++}$system, $\mathrm{Ba}^{++}$appeared more strongly held at all percentages of $\mathrm{Mg}$ in the resin. These results were explained on the basis of formation of slightly dissociated complexes of the alkaline-earth metals with the carboxylic groups of the exchanger.

The results in attapulgite clay for the $\mathrm{Na}^{+}-\mathrm{K}^{+}, \mathrm{Na}^{+}-\mathrm{Rb}^{+}$, and $\mathrm{Na}^{+}-\mathrm{Cs}^{+}$ systems showed marked selectivity. The selectivity numbers were functions of the percentage of $\mathrm{Na}$ in the clay. The differences in selectivity were 
greater in the $\mathrm{Na}^{+}-\mathrm{Cs}^{+}$system than in the $\mathrm{Na}^{+}-\mathrm{Rb}^{+}$system and, in the $\mathrm{Na}^{+}-\mathrm{Rb}^{+}$system, greater than in the $\mathrm{Na}^{+}-\mathrm{K}^{+}$system. The results were broadly understood on the basis of the bifunctional character of the clay.

The differences in the selectivity numbers for the alkaline-earth metals in the clay ( $\mathrm{Mg}, \mathrm{Ca}, \mathrm{Sr}$, and $\mathrm{Ba}$ ) are small as compared with those of the alkali metals. At high percentages of $\mathrm{Mg}$ in the clay (80 to 97 percent) the selectivity numbers increase in the order ${ }_{\mathrm{Ca}}^{\mathrm{Mg}} K_{s}<{ }_{\mathrm{sr}}^{\mathrm{Mg}} K_{s}<{ }_{\mathrm{Ba}_{a}}^{\mathrm{Mg}_{s}} K_{s}$; at lower percentages of $\mathrm{Mg}$ ( 5 to 60 percent) the values of the selectivity number fall below unity, meaning that $\mathrm{Mg}^{++}$appears more strongly held than $\mathrm{Ca}^{++}$, $\mathrm{Sr}^{++}$and $\mathrm{Ba}^{++}$. This suggests that there are other effects besides hydration which affect the entry of ions into the exchanger.

In general, the resin behaved as a moderately strong electrolyte with respect to the alkali metals. It behaved like a weak electrolyte with respect to the alkaline-earth metals.

Attapulgite clay behaved like a weak electrolyte with respect to both the alkali metals and alkaline-earth metals. The results of the selectivitynumber curves for the clay resembled those of a bifunctional cation exchanger and a high cross-linkage resin.

\section{RESUMEN}

Se determinaron los números de selectividad para diferentes pares de cationes en un intercambiante sintético de cationes del tipo carboxílico y en la arcilla atapulgita.

Los resultados de la resina sintética para los sistemas $\mathrm{Na}^{+}-\mathrm{K}^{+}, \mathrm{Na}^{+}-\mathrm{Rb}^{+}$, y $\mathrm{Na}^{+}-\mathrm{Cs}^{+}$demostraron que la resina no tenía una selectividad marcada para ninguno de estos cationes. La fase de la resina se comportó como una solución concentrada de sales. Por lo tanto, las diferencias en los números de selectividad $\left(K_{a}\right)$ fueron atribuídos a diferencias en los coeficientes de actividad en la fase de la resina.

En los sistemas de los alcalinotérreos $\left(\mathrm{Mg}^{++} \mathrm{Ca}^{++}, \mathrm{Mg}^{++} \mathrm{Sr}^{++}\right.$, and $\mathrm{Mg}^{++}$ $\mathrm{Ba}^{++}$) la resina demostró más diferencias en selectividad entre sus miembros que para los miembros de la serie de los álcalis. Los números de selectividad son una función del porcentaje de $\mathrm{Mg}$ en la resina. En el sistema $\mathrm{Mg}^{++} \mathrm{Ca}^{++}$, $\mathrm{Mg}^{++}$aparece más fuertemente atado en los casos de porcentajes bajos de $\mathrm{Mg}$ mientras que en el sistema $\mathrm{Mg}^{++}-\mathrm{Ba}^{++}, \mathrm{Ba}^{++}$aparece más fuertemente atado a todos los porcentajes de Mg en la resina. Estos resultados se explicaron a base de que los alcalinotérreos forman complejos que se disocian muy poco con los grupos carboxílicos de la resina.

Los resultados en la arcilla atapulgita para los sistemas $\mathrm{Na}_{-}^{+} \mathrm{K}^{+}$, $\mathrm{Na}^{+}-\mathrm{Rb}^{+}, \mathrm{y} \mathrm{Na}{ }_{-}-\mathrm{Ca}^{+}$demostraron que había una selectividad muy marcada para estos cationes. Los números de selectividad son una función del porcentaje de $\mathrm{Na}$ en la arcilla. Las diferencins en selectividad son mayores en 
el sistema $\mathrm{Na}^{+}-\mathrm{Cs}^{+}$que en el sistema $\mathrm{Na}^{+}-\mathrm{Rb}^{+}$y las del sistema $\mathrm{Na}^{+}-\mathrm{Rb}^{+}$ son mayores que las del sistema $\mathrm{Na}^{+}-\mathrm{K}^{+}$. En general, estos resultados fueron interpretados a base del carácter bifuncional de la arcilla.

Las diferencias en los números de selectividad para los alcalinotérreos $(\mathrm{Mg}, \mathrm{Ca}, \mathrm{Sr}, \mathrm{Ba})$ en la arcilla son pequeñas comparadas con las de la serie de los álcalis. A porcentajes altos de $\mathrm{Mg}$ en la arcilla (80 a 97 por ciento) los números de selectividad aumentan en el orden ${ }_{\mathrm{Ca}_{\mathrm{g}}}^{\mathrm{Mg}_{\mathrm{a}}}<{ }_{\mathrm{Br}}^{\mathrm{Mg}} K_{\mathrm{s}}<{ }_{\mathrm{Ba}}^{\mathrm{Ma}_{\mathrm{g}}} K_{\mathrm{a}}$, pero a porcentajes bajos de $\mathrm{Mg}$ ( 5 a 60 por ciente) los valores del número de selectividad son menores de uno, queriendo decir que $\mathrm{Mg}^{++}$aparece más fuertemente atado que $\mathrm{Ca}^{++}, \mathrm{Sr}^{++}$, y $\mathrm{Ba}^{++}$. Esto sugiere que hay otros efectos, además del de hidratación que afectan la entrada de los iones a la arcilla.

En general, la resina se comporta como un electrolito moderadamente fuerte con respecto a la serie de los álcalis. Se comporta como un electrolito débil con respecto a la serie de los alcalinotérreos.

La arcilla atapulgita se comporta como un electrolito débil con respecto a ambas series. Los resultados de las curvas de números de selectividad en la arcilla se parecen a las de un intercambiante sintético de cationes bifuncional y a los de una resina de alto enlace cruzado.

\section{LITERATURE CITED}

1. Bauman, W. C., and Eichhorn, I., Fundamental properties of a synthetic cation exchanger resin, J. Amer. Chem. Soc., 69 2830-48, 1947.

2. Bolan, T. R., The Donnan Equilibrium, G. Bell and Sons, Ltd., London, England, 1932.

3. Bonner, O. D., Equilibrium studies of some monovalent ions of Dowex $50, J$. Phys. Chem., 68 183-5, 1954.

4. Caroz, J. P., and Deuel, H., Ionengleichgewichte an Einem Bifunktionellen Kationenaustauscher, Helv. Che. Acta 39 Fasc. 5, (147) 1227, 1956.

5. Kunin, R., and Myers, R. J., Ion Exchange Resin, John Wiley and Sons, Inc., New York, N. Y., Chapman \& Hall, Limited, London, England, 1950.

6. Lowen, W. K., Stoenner, R. W., Argensinger, Jr., W. J., Davidson, A. W., and Hume, D. N., Studies of cation exchange equilibria on a synthetic resin, $J$. Amer. Chem. Soc., 76 2666-74, 1951.

7. Martell, A. E., and Calvin, M., Chemistry of the Metal Chelate Compound, Prentice Hall, Inc., New York, N. Y., 1953.

8. Metson, A. J., Methods of Chemical Analysis for Soil Survey Samples, R. E. Owen, Government, Printer, Wellington, New Zealand, 1956.

9. Riechenberg, D., Pepper, K. W., McCurle, W., Properties of ion exchange resins in relation to their structure, $J$. Chem. Soc., $1493-9,1951$.

10. Samuelson, O., Ion Exchangers in Analytical Chemistry, John Wiley \& Son, Inc., New York, N. Y., 1953.

11. Spinner, I. H., Curie, J., and Craydon, W. F., Preparation of ion exchanger resin, Canadian J. Chem., 32 143-52, 1954.

12. Tschapeck, M., Química Coloidal del Suelo, Comunicaciones del Instituto Nacional de Investigaciones de las Ciencias Naturales Anexo al Museo Argentino de Ciencias Naturales, Bernandina Rivadavia, 1949. 
13. Welcher, F. J., The Analytical Uses of Ethylenediaminetetra-acetic Acid, D. Van Nostrand Company, Inc., New York, N. Y., 1958.

14. Whitehorn, J. C., Permutit as a reagent for amines, J. Biol. Chem., 56 751-64, 1923.

15. Wiegner, G., Some physico-chemical properties of clay: I. Base exchange or ionic exchange, $J$. Soc. Chem. Ind., 60 667, 1931.

16. Wiklander, L., Studies on ionic exchange with special reference to the conditions in soil, Ann. Royal Agr. Col. of Sweden, 141946. 